\title{
Climate Field School (SLI) as a Strategy for Improving Farmers Capacity in Pekalongan District in Climate Change Adaptation and Mitigation in the Digital Innovation 4.0 Era
}

\author{
Eva Banowati ${ }^{1}$, Juhadi ${ }^{2}$, Nur Azizah ${ }^{3}$, Septa Mauliyatun $\mathrm{NC}^{4}$ \\ \{evabanowatigeografi@mail.unnes.ac.id ${ }^{1}$, juhadigeo@mail.unnes.ac.id ${ }^{2}$, nuraziz4hh@gmail.com ${ }^{3}$, \\ septamauliya054@gmail.com $\left.{ }^{4}\right\}$ \\ 1,2,3,4 Universitas Negeri Semarang, Indonesia
}

\begin{abstract}
Pekalongan is included in the RANMAPI (National Action Plan for Climate Change Mitigation and Adaptation) and is the mandate of the RPJMN (Medium Term National Development Plan). Among the plans realized in Climate Field Schools (SLI) as one of the facilitaties of Pekalongan District Government to farmers in climate change adaptation and mitigation oriented to sustainable agriculture. At a minimum it can achieve food self-sufficiency. SLI applies the andragogical approach (Knowle, 1980) to learning by doing/ learning by experiencing which provides farmers with the ability to assess climate change for the dynamics of independence values (Umriyah, 2012) in a learning process. This whole pattern is designed to open opportunities for SLI farmers to learn to interact with the reality of climate change. Especially changes in rainfall patterns, extreme climate events in the form of floods and droughts, and finding their own knowledge and principles contained therein. From the analysis, the problem in this research is how the strategy of adaptation and mitigation of farmers in climate change in the era of innovation 4.0. Quantitative approach is applied. Primary data sources were revealed through observation, interviews, and in-depth interviews with farmers and SLI teachers. Rainfall data and the area of rice fields were obtained from Department of Agriculture and Husbandry and Central Bureau of Statistics (BPS) of Pekalongan Regency. Data analysis used cross tables to find the most influential sub-variables. Followed by descriptive analysis by checking the results of indeptinterview. The implementation of SLI is a step in implementing building sustainable agriculture. The ability of adaptive capacity to respond to climate change is adapted to the existing agroclimate of agricultural land. Pekalongan Regency has two harvest areas, namely areas with a production of 3-4 tons per hectare and a lower area potentially reaching 9 tons per hectare. The strategy by farmers to minimize crop failures, namely: farmers adjust the calendar and cropping patterns, selecting types of intercrops with dynamic weather. Mitigation capabilities are in the form of active activities of farmers' movements in the selection of rice varieties that are in accordance with local conditions, the application of macak-irrigation techniques. SLI effectiveness was checked with secondary data which showed that Pekalongan Selatan Subdistrict was 425.33 hectares $(63.61 \%)$ of the total paddy field area (641.49 hectares) in Pekalongan Regency, with a production value of approximately 4443.05 tons of grain. The calculation of milled dry grain (GKG) production amounted to $2726.33(63.606 \%)$ of the total GKG district.
\end{abstract}

Keywords: Adaptation, Farmer Capacity, Mitigation, Climate Change. 


\section{Introduction}

Pekalongan is included in the RANMAPI (National Action Plan for Climate Change Mitigation and Adaptation) and this is the mandate of the RPJMN. Considering that this regency experienced a rise in sea water which had an effect on the loss of 100 percent of agricultural land which stretched across eight villages. The land that was used by the community for rice fields, since 2007 cannot be planted again. As a result of further decline in farmer income and vulnerability to food availability (Wulansari, 2017). The attitude and actions of the Pekalongan Regency government including the existence of Climate Field Schools (SLI) is one of facilitaties to farmers in climate change adaptation and mitigation oriented to sustainable agriculture, since rice fields are the source of food and family income. SLI is one of BMKG's (Meteorology Climatology and Geophysics Council) efforts in increasing climate literacy and dissemination of climate information for agriculture (Dewi, 2018), according to Presidential Instruction No. 5 of 2011, on securing national rice production in the face of extreme weather and climate conditions. Besides SLI is also in line with the Government's Nawacita program, which is the seventh Nawacita program to realize economic independence.

Farmers who are participatimg in climate field schools are expected to increase their understanding of life-related information on climate. So that the negative impact of crop failures or a decrease in farmer productivity are avoidable (Heriazal, in Amalo, 2019). For this reason, understanding or literacy in all aspects of life is needed by the people in the digital innovation era 4.0 (Banowati, et al., 2018) to deal with all possible consequences of climate change in order to minimize losses caused by crop failures or puso which reduce farmers' income. Masud, et al. (2012) explained that the effects of climate change affect the net income of paddy farmers as a result of the influence of climate variables such as temperature and rainfall (Banowati, et al., 206; Banowati and Wisika, 2017).

According to the report of United Nations Development Program-Indonesia (Irawan, 2011: 67) states that the impact of climate change is likely to be more severe in poor countries and islands, besides causing sea level rise can also increase the chances of extreme weather that can trigger food insecurity due to crop failure. The conditions experienced by Kesesi and its surrounding districts - Pekalongan Regency, which are threatened with crop failure due to the attack of planthopper pests on rice plants, are just waiting for the harvest day, but suddenly the rice plants become dry (Radar Pekalongan, 2019). Bizikova (2012) also emphasizes that adaptation planning in agriculture can be improved by developing skills and mutual learning among stakeholder groups, research and policy makers, and through the development of interactive, sustainable institutional capabilities (Banowati et al., 2016).

SLI implementation is the realization and program of the Agriculture Service in collaboration with BMKG in the form of non-formal education that aims to provide understanding to farmers regarding agro-climate analysis skills. Ministry of Agriculture (2011) states that almost all agricultural sub-sectors are vulnerable to climate change, so education for farmers is needed so that adaptives are more innovative in mitigating the effects of climate change. The history of the establishment of SLI in early 1990 in Central Java and D.I Yogyakarta, began with small discussion activities, a kind of farmer Focus Group Discussion (FGD) as participants and several guiding officers / activists of Pest and Plant Observation (PHT). Farmers only listen to reviews and theoretical discussions of the guides. Along with its development, it has been updated by paying attention to the element of education in extension agents namely by going directly to agricultural land. At least it can achieve food self-sufficiency. 
SLI applies the andragogical approach (Knowles, 1980) with learning by doing / learning by experiencing methods that provide farmers with the ability to assess climate change and the dynamics of independence values (Umriyah, 2012). In a learning process Knowles (1980) is more focused on problems (problem-centered) and requires encouragement and motivation in overcoming the problem in accordance with the behavior desired. This whole pattern is designed to open opportunities for SLI participating farmers to act quickly in the context of adaptation and mitigation (risk reduction) reality of climate change. In the opinion of Setiana (2005) states that the purpose of adult education is essentially the occurrence of a process of changing behavior towards a better and more profitable direction that can only occur if there are fairly basic changes in the form or increase in knowledge, skills and attitudes.

The curriculum framework of SLI is based on the learning area which is the curriculum content needed to overcome the problem of variation and climate change which consists of adaptation and mitigation activities. The preparation of the curriculum is carried out with criteria for curriculum elements developed together, the material to be studied using a framework created with farmers in a participatory manner. The pattern of the SLI approach is based on two main challenges related to maintaining local wisdom, namely local ecological diversity and the role of farmers who must become professionals in their own land. Accommodating Kamil's opinion (2009) the role of the community in non-formal education is divided into two main points: 1) Society as a source of learning, the need for a basic understanding of the role of society in changes that occur in the community can be used as a basis for non-development and development formal so that it determines the level of community participation in the development of non-formal education programs; and 2) Society as the target of non-formal education, which can increase community participation in programs related to improving their abilities, skills and qualities. Although SLI in Pekalongan Regency for farmers is completed, SLI participants always apply their understanding and disseminate to other farmers. This condition is in line with the alerts of BMKG (Dewi, 2018), which at present Indonesia is entering the era of 4.0 digital innovation to facilitate and accelerate services for farming communities. In order farmers to understand information related to weather, climate and air quality more quickly by utilizing mobile phone technology.

On a small scale in this study, mitigation in the form of awareness in reducing the use of chemical fertilizers by returning to organic fertilizer. As for adaptation mainly to changes of rainfall patterns, extreme climate events in the form of floods and droughts, and finding their own knowledge and principles contained therein. Referring to the opinion of Cohen (1992), the adaptation of Banyuurip farmers learned to adjust to their environment, namely their daily movement. Furthermore, mitigation and adaptation refers to the flow of the Blache possibilism (1845-1919) in the implementation of the genre de vie that the production process is a form of activity chosen by humans from various possibilities that exist on the face of the earth. In the end, with the increasing knowledge about the dynamics of the agro-climate, the intelligence and ability of farmers to deal with the climate are also increasingly closely related to the continuity of business. This is needed to carry out more specific agricultural cultivation to minimize the decline in production due to the impact of climate phenomena that occur from various natural factors, for example the impact of increasing average rainfall in an area causes an increase in the development of Plant Pest Organisms (OPT) so that the impact Another cause is disruption of plant growth (rice).

In line with the agreement in the field of geography, SLI is an education program that teaches weather and climate factors in daily life, actions to adapt and mitigate climate change are the result of human interaction with nature (Banowati, 2011) using a spatial approach and ecological approach. From the analysis, the problem in this study is how the strategy of adaptation and 
mitigation of farmers in climate change and how the effectiveness of the SLI curriculum in the Learning Areas of Pekalongan Regency.

The results of this study can be used as reference material and consideration for the government in handling food vulnerability in the scope of regional and national areas. In addition, it can be used as a reference in establishing regional regulations regarding the policy of the existence of SLI as an effort to teach the farmers community as the main pillar of food providers / producers. The sustainability target of this SLI, in addition to increasing farmers' knowledge and the local agricultural system that has increased its long-term stage by the decrease of rural poverty.

\section{Research Method}

Case study research in a group of farmers participating in SLI to obtain further descriptions with a quantitative approach conducted in South Pekalongan District. The sample of this study was 25 farmers consisting of 12 SLI farmers and 13 non-SLI farmers. Primary data sources were revealed through documentation, observation and in-depth interviews with farmers. Data analysis used cross tables to find influences on the 2 affected sub-variables, and to find trends. Continued spatial analysis and a descriptive environmental analysis were examined by the results of the indept interview.

\section{Findings and Discussion}

The implementation of SLI is an implementation step to support food security for farmers in the context of sustainable agriculture. The ability of adaptive capacity to respond to climate change is adapted to the existing agro-climate of agricultural land. SLI held in South Pekalongan Subdistrict lasted 120 days with 12 meetings, followed by 25 farmers, 5 of whom were guiding farmers from the Advanced Farmers Group - the administration of Banyurip Ageng Village. Farmers as end-users interact through field extension workers.

Table 1. SLI Participants Profile Kelompok Tani Maju

\begin{tabular}{|c|c|c|c|}
\hline \multirow{2}{*}{\multicolumn{2}{|c|}{ Indicator }} & \multicolumn{2}{|c|}{ Condition ( $\Sigma$ Farmers) } \\
\hline & & 2014 SLI & 2019 \\
\hline \multirow{5}{*}{1} & \multicolumn{3}{|l|}{ Age Structure } \\
\hline & $24-37$ & 13 & 6 \\
\hline & $>37-48$ & 5 & 10 \\
\hline & $>48-60$ & 7 & 5 \\
\hline & $>60$ & 0 & 4 \\
\hline \multirow{4}{*}{2} & \multicolumn{3}{|c|}{ Formal Education Level } \\
\hline & Elementary School & 9 & 9 \\
\hline & Mid-High School & 7 & 7 \\
\hline & High School & 9 & 9 \\
\hline \multirow{5}{*}{3} & \multicolumn{3}{|c|}{ Mastery of Area of Agricultural Land } \\
\hline & $<1$ & 6 & 8 \\
\hline & $>1-1,5$ & 5 & 4 \\
\hline & $>1,5-2$ & 3 & 2 \\
\hline & $>2$ & 1 & 1 \\
\hline 4 & \multicolumn{3}{|c|}{ Mobile Phone Ownership } \\
\hline
\end{tabular}




\begin{tabular}{|l|l|c|c|}
\hline & Hand Phone & 23 & 4 \\
\cline { 2 - 4 } & Smart Phone & 0 & 17 \\
\hline
\end{tabular}

Source: Azizah, et al., 2015; Banowati, et al., 2019

The learning experience of SLI participants and the dynamics of indicator conditions are reflected in the extent of land tenure and ownership of smart phones as a means to increase understanding of the effects of climate change. The results of the study from indepth interview data to $12(48 \%)$ members of the Advanced Farmers Group who were SLI participants in 2014, admitted that until now they had accessed the official BMKG website for disaster management (Constitutions Number 24 of 2007).

The capacity of farmers in the post-SLI implementation period can be seen from the ability of farmers participating in SLI to disseminate to other farmers in response to climate change due to technological advances and the ability to use technology for the sake of fulfilling their needs. Some indicators of increasing farmers' capacity to save their housing businesses are explained as follows.

The ability to disseminate SLI results to other farmers in their immediate environment so that they can innovate independently if the agricultural crops they manage are damaged, either from pest disturbances or climate change in the form of droughts or changing rainfall patterns. The form of dissemination is adjusted to the andragogical approach with the use of personal discussions and in small groups according to SLI material as contextual lessons learned in Banyuurip Ageng Sub-District. Agricultural land in this village is prone to flooding/ inundation (Azizah et al., 2015). It was further explained that the condition was caused by the relatively low existing land so that it is prone to inundation when rainfall is high enough.

The mitigation activities include a study of the function and content of organic matter and soil absorption power carried out by dripping a solution of A $\alpha$ Bifiridil and $\mathrm{HCl}$ on the soil. Management of irrigation systems to maintain water availability. Then the adaptation activities are as follows: conducting a study of advancing and reversing crops (paddy), determining which plants are adapted to water content and the use of inorganic pesticides according to the right dose (Azizah et al., 2015; Banowati et al., 2019). Another dissemination material is by showing the Map of Plant Disturbance Organisms (OPT) - Wereng in Banyurip Ageng Village. Referring to the opinion (Syahri, 2013) that the dynamics and development of OPT is an implication of climate change that greatly affects agricultural conditions.

Ability to use smart phones to access information from BMKG. Changes and developments in information technology and rapid communication, social and political dynamics will influence the choice of communication and public information dissemination strategies. This is a challenge as well as a record for government public and public relations officials to adjust to these developments and changes. Pekalongan Regency has two harvest areas, namely upper and lower areas. Upper area produces of 3-4 tons per hectare while lower area potentially reaches 9 tons per hectare.

The farmers strategies to minimize crop failures, namely: adjusting the calendar and cropping patterns, selecting types of intercrops with weather that is always dynamic. Adjustments made by farmers are inseparable from the ability to access information from android smart phones on the https://.bmkg.go.id page about the daily weather forecasts of Pekalongan and other cities. 
Table 2. Farmers' Understanding Toward Weather

\begin{tabular}{|c|c|c|c|c|}
\hline \multirow{2}{*}{ Weather Elements } & \multicolumn{3}{|c|}{ Understanding } & \multirow{2}{*}{ Criterias } \\
\cline { 2 - 4 } & \multicolumn{3}{|c|}{ Numbers of farmers } & \multirow{2}{*}{ Undertsand } \\
\cline { 2 - 4 } & High & Moderate & Low & \\
\hline Precipitation & \multicolumn{3}{|c}{} \\
\hline a. Time & 11 & 12 & 2 & \\
\hline b. Volume & 4 & 13 & 8 & \multirow{2}{*}{ Do not understand } \\
\hline c. Influence & 22 & 3 & 1 & \\
\hline Humidity & 1 & 8 & 17 & \multirow{2}{*}{ Understand } \\
\hline a. Level & 4 & 14 & 7 & \\
\hline b. Function & 0 & 3 & 22 & \\
\hline c. Effect & \multicolumn{3}{|c|}{} \\
\hline Wind & 16 & 3 & 6 & \multirow{2}{*}{} \\
\hline a. Direction & 4 & 17 & 4 & \\
\hline b. Speed & 25 & 0 & 0 & \\
\hline c. Effect & \multicolumn{3}{|c|}{} \\
\hline
\end{tabular}

Source: Primary Data, 2019.

The ability to apply the knowledge in managing agricultural land so that productivity increases. The indicators used to study used secondary data from several publications, including Said's (2015) research, which revealed that the area of rice in the District of South Pekalongan was 425.33 hectares $(63.61 \%)$ of the total rice field area (641.49 hectares) in Pekalongan Regency, with a production value of approximately 4443.05 tons of grain. The calculation of milled dry grain (GKG) production amounted to $2726.33(63.606 \%)$ of the total GKG district.

Besides the in-depth interview results (Banowati et al., 2019) to 4 farmers who had attended SLI, they learned that in Kuripan Village Yosorejo had a ten hectare drought of rice field(Saptohutomo, 2015). This village in the same sub-district where SLI was carried out, but Banyurip Ageng Village farmers were able to manage irrigation using the macak-macak irrigation technique, ie wetlands without wet water (continuous irrigation) proved to be more efficient in saving water. The ability to apply at the mitigation level is in the form of active activities of farmers' movements in the selection of rice varieties that are in accordance with local conditions, use of inorganic fertilizers, and post-harvest actions. SLI effectiveness was examined by secondary data which showed that Pekalongan Regency was able to realize a sustainable rice field of 42,281 thousand hectares (BPS, 2014; 2017), but there was a decline in production. In 2014 rice production was 234,148 tons while in 2017 it was 219 thousand tons. Statistically a surplus of 109 thousand tons, because domestic consumption is around 110 thousand tons.

\section{Conclusion}

SLI in Pekalongan Regency showed success, an indicator of success in increasing farmer capacity is demonstrated by the ability of farmers to disseminate to other farmers, the ability to access weather information, and the ability to apply their knowledge in managing rice fields. Mitigation capabilities in the form of active activities of farmers movements in the selection of rice varieties that are in accordance with local conditions, water management and macak-macak / no longer use more techniques. SLI effectiveness was examined by secondary 
data which showed that Pekalongan District was able to realize sustainable rice fields despite a decline in production. Statistical data shows that food sufficiency is maintained, namely a surplus of 109 thousand tons, as domestic consumption is around 110 thousand tons.

\section{References}

Admin 1. 2019. Rice fields attacked by slopes, farmers forced to harvest early. Radar Pekalongan. Kajen, March 2019.

Amalo, Palce. 2019. Sekolah Lapangan Iklim Supports Food Security. Media Indonesia. Uploaded Selasa, 02 April 2019 Downloaded 06 June 2019.

Banowati, Eva. Indrayati, \& Juhadi. 2017. Rural Forest Social Engineering. Purwokerto: CV IRDH.

Banowati, Eva \& Wisika Suci. 2017. Developing the under stand cropping system (PLDT) for sustainable livelihood. Management of Environmental Quality. Volume 28, Issue 5 2017.

Cohen, Bruce J. 1992. An Introduction to Sociology. Jakarta: PT Rineka Cipta.

Dewi, ML. 2018. Climate Field School Collaboration between BMKG and the Community to Increase Indonesian Food Production. Berita BMKG. Uploaded 05 May 2018. Downloaded 06 June 2019.

Kamil, Mustafa. 2009. Non-formal Education Development through the Center for Teaching and Learning Activities (PKBM) in Indonesia. Jakarta: Alfabeta.

Ministry of Agriculture. 2011. General Guidelines for Adaptation to Climate Change in the Agriculture Sector. Jakarta (ID): Agricultural Research and Development Agency, Ministry of Agriculture.

Knowles, M.S. 1980. The Modern Practice of Adult Education, From Pedagogy to Andragogy Revised and Update. Englewood Cliffs, NJ: Cambridge Adult Education

LPHP. 2007. Report on Climate Field School Activities (SLI). Group scale Pemalang: Food Crop Agriculture Service.

Said, Husen Ibnu, et al. 2015. Analysis of Rice Production with Remote Sensing and Geographic Information Systems in Pekalongan City. Jurnal Geodesi UNDIP, Volume 4/ No. 1/ 2015.

Saptohutomo, Aryo Putranto. 2015. In Pekalongan, drought paddy fields reach 10 hectares. Merdeka.com. Uploaded Friday, 31 July 2015. Downloaded 06 June 2019.

Umriyah, A. Yulianto, N. Hindarto 2012. Use of Teaching Materials with Andragogical Approach as an Effort to Improve Creativity and Learning Outcomes of RSBI High School Students. Jurnal Pendidikan Fisika Indonesia 8 (2012) 68-73.

Wulansari, Amalia. 2107. Climate Change and Women. Legal Ideas, Media Online. Publisher Slamet Hariyanto \& et al. 